\title{
ANTIOXIDANT ACTIVITY AND PHYTOCHEMICAL SCREENING OF THE APRICOT POMACE EXTRACT: EXPERIMENTAL AND THEORETICAL STUDIES
}

\author{
Victoria Vorobyova ${ }^{1,}{ }^{凶}$, Anastasiia Shakun ${ }^{1}$, Olena Chygyrynets' ${ }^{1}$, \\ Margarita Skiba ${ }^{2}$, Julia Zaporozhets ${ }^{1}$
}

https://doi.org/10.23939/chcht14.03.372

\begin{abstract}
The aim of this study was to determine the chemical composition and antioxidant potential of the apricot pomace extract (ACE). The apricot pomace was extracted using ethanol (EtOH), silicone (D5) and a mixture of silicone and ethanol. The chemical constituents were analyzed by gas chromatography-mass spectrometry (GC-MS). The antioxidant capacity was evaluated using a variety of antioxidant assays (total antioxidant activity, reducing power and catalase activity). Quantum chemical descriptors such as the frontier orbital energies $\left(E_{\text {НОMO }}\right.$ and $\left.E_{L U M O}\right)$, the energy gap between $E_{L U M O}$ and $E_{H O M O}$ $(\Delta E)$, hardness, and electrophilicity index have been calculated and discussed.
\end{abstract}

Keywords: chemical characterization, apricot pomace extract, quantum chemical, descriptor antioxidant activity.

\section{Introduction}

The extracts of plants and food, forest or agroindustrial wastes, particularly from fruits and vegetables, have gained increasing interest among the scientific community because studies have indicated that they are valuable sources of "green" organic substances [1-3]. In this context, the cheap waste products are particularly interesting for the environmental and economic benefits resulting from their re-use. Agro-industrial by-products are cheap, abundant and sustainable resources which contain compounds with antioxidant, cytotoxic and antimicrobial activities that can be used for synthesis of nanoparticles [4, 5], production of food additives [6], as a natural preservative and antioxidant in cosmetic products [7], for inhibition corrosion of metals in corrosive media

\footnotetext{
${ }^{1}$ National Technical University of Ukraine "Igor Sikorsky Kyiv Polytechnic Institute",

37, Peremogy Ave., 03056 Kyiv, Ukraine

${ }^{2}$ Ukrainian State Chemical-Engineering University,

8, Gagarina Ave., 49066 Dnipro, Ukraine

vorobyovavika1988@gmail.com

(C) Vorobyova V., Shakun A., Chygyrynets' O., Skiba M., Zaporozhets J., 2020
}

$[8-11,14]$. Some studies have already been done on byproducts, which could be potential sources of antioxidants [1-5]. Importantly, the correlation between antioxidant/ free radical scavenging activity of the extracts was observed, as well as the effectiveness of the nanoparticles synthesis [5, 12] and the inhibition action [13, 14]. So, it is an interesting and useful task to find new sources for highlighting "green" antioxidant compounds and to obtain various products.

Apricot fruits (Prunus armeniaca L.) are valued and highly consumed fruits all over the world, both for their flavour and for nutritional qualities. Ukraine is one of the major apricot producers in the world with the approximate annual yield of 160,000 t/year of fresh fruits, seeds and kernels. About $20 \%$ of the harvest is waste from processing of this raw material [15]. It is hypothesized that "green" antioxidants of apricot pomace would be an effective alternative to synthetic organic substances (antioxidants) for chemical industry.

The most convenient way of obtaining natural antioxidants is extraction. Different solvent systems can be used for the extraction of antioxidant compounds from plant material. An important concern related to the extraction of natural compounds uses is the desired limitation of toxic solvents. Extraction efficiency is influenced by various factors, such as a method of extraction, solvent type, contact time, temperature, solid to solvent ratio, and particle size $[16,17]$. Solvent extraction is frequently used for isolation of antioxidants and extraction yield is dependent on the solvent and method of extraction, due to the different antioxidant potentials of compounds with different polarity. To our knowledge, a comparative study of the influence of the solvent on the antioxidant properties of apricot pomace has not been conducted previously. On the other hand, most of the previous experiments have been limited by using a single solvent for extraction, either with alcohol or with water. Therefore, the objectives of this study were to evaluate apricot pomace as sources of natural antioxidant using different extracting solvents to determine their antioxidant capacities. Solvents of varying polarity were 
used: ethanol, silicone (cyclopentasiloxane), system of solvents silicone/ethanol.

\section{Experimental}

\subsection{Materials}

The apricot (Prunus armeniaca L.) cultivar known under local name "Favorite" were harvested (during July 2018) in two geographical regions of Ukraine (Kherson, Mykolaiv). The apricot pomace was supplied by an agro-food company (Vinni Frut) from the city of Vinnytsia, Ukraine.

Analytical grade ethanol (EtOH), silicone (cyclopentasiloxane(D5)) and other chemicals were obtained from the general suppliers. All reagents were of analytical grade and were purchased from Sigma-Aldrich (Milan, Italy).

Preparation of extracts. To extract the complex of antioxidant active compounds, the maceration method was used, with a 2:1 ratio of plant raw materials to a solvent at room temperature for $48 \mathrm{~h}$. Three common solvents were used for the extraction of the apricot pomace (Prunus armeniaca L.) including ethanol (EtOH), silicone (cyclopentasiloxane (D5)), system of solvents silicone/ethanol (D5:EtOH = 1:5, v/v). The homogeneous mixture was filtered with filter paper. The resulting extract was divided into 2 parts, one from which was left in the native state, and the other filtered fraction was concentrated to dryness under reduced pressure on rotary.

\subsection{Identification of Chemical Profile}

The Prunus armeniaca L. extracts in different solvents were analyzed by GC-MS to identify the number of compounds. Analytical conditions: HP-5MS capillary column $(30 \times 0.25 \mathrm{~mm})$, helium as a carrier gas, thickness of the phase $0.25 \mu \mathrm{m}$, flow of the carrier gas $1.5 \mathrm{ml} / \mathrm{min}$. The injector temperature was maintained at $523 \mathrm{~K}$; the detector temperature was held at $553 \mathrm{~K}$. The column oven temperature was programmed as follows: an initial temperature of the column was $373 \mathrm{~K}$; heating rate of the column (temperature gradient) was $10 \mathrm{~K} / \mathrm{min}$ up to $553 \mathrm{~K}$, the mass range was monitored from 30 to $500(\mathrm{~m} / \mathrm{z})$; the sample was introduced with a split flow of $15 \mathrm{ml} / \mathrm{min}$; the volume of the sample was $2 \mu \mathrm{l}$. The identification of components was based on Willey and NIST libraries as well as comparison of their retention indices [18].

\subsection{Antioxidant Assays}

The ethanol, silicone and ethanol/silicone extracts $(1: 5 \mathrm{v} / \mathrm{v})$ of the apricot pomace were evaluated for antioxidant activity by 3 methods.

\subsubsection{Determination of total antioxidant capacity by phosphomolybdenum method}

The total antioxidant capacity of the extracts different solvents was evaluated by the phosphomolybdenum method as described by Prieto et al. [19]. The analysis is based on the reduction of $\mathrm{Mo}(\mathrm{VI})$ to $\mathrm{Mo}(\mathrm{V})$ with an extract and, as a consequence, the formation of a green phosphate $\mathrm{Mo}(\mathrm{V})$ complex at acidic $\mathrm{pH}$. The extract: reagent ratio was $1: 10 \mathrm{v} / \mathrm{v} .0 .5 \mathrm{ml}$ of each sample solution and ascorbic acid $(100 \mu \mathrm{g} / \mathrm{ml})$ were taken for the experiment with $5 \mathrm{ml}$ of reagent $(0.6 \mathrm{M}$ sulfuric acid, $28 \mathrm{mM}$ sodium phosphate and $4 \mathrm{mM}$ ammonium molybdate). The blank solution contained $5 \mathrm{ml}$ of the reagent solution and the corresponding volume of the solvent, which was used for the sample. All tubes were closed and incubated in a boiling water bath at $368 \mathrm{~K}$ for $90 \mathrm{~min}$. After the samples had been cooled to room temperature, the absorbance of the solution of each sample was measured at $695 \mathrm{~nm}$ against the blank using a UV-Vis spectrophotometer (UV-5800PC spectrophotometer, FRU, China).

\subsubsection{Determination of antioxidant activity in terms of reducing power}

$\mathrm{Fe}(\mathrm{III})$ reduction is often used as an indicator of electron donating activity, which is an important indicator of the phenolic antioxidant effect [20]. Extracts, which have reduction potential, react with potassium ferricyanide $\left(\mathrm{Fe}^{3+)}\right.$ to form potassium ferrocyanide $\left(\mathrm{Fe}^{2+}\right)$, which then reacts with ferric chloride to form ferric ferrous complex that has an absorption maximum at $700 \mathrm{~nm}$. To prepare the reaction solution, different amounts of the extract $(0.005,0.01,0.015,0.02$ and $0.025 \mathrm{~g}$ ), were mixed after the rotary evaporator and dissolved in an appropriate solvent $(1 \mathrm{ml})$ plus $1 \mathrm{ml}$ phosphate buffer $(0.2 \mathrm{M}, \mathrm{pH} 6.6)$ and $1 \mathrm{ml}$ of potassium ferricyanide solution (1\%). The resulting solution was incubated at $323 \mathrm{~K}$ for 20 minutes. Then, $1 \mathrm{ml}$ of trichloroacetic acid (10\%) was added to terminate the reaction and was quenched under running water for $5 \mathrm{~min}$. The resulting mixture was centrifuged at $3000 \mathrm{rpm}$ for $10 \mathrm{~min}$. An aliquot of $2 \mathrm{ml}$ was then removed from the top layer of each solution, to which $2 \mathrm{ml}$ of distilled water and $0.4 \mathrm{ml}$ of ferric chloride solution $(0.1 \%)$ were added. The solution absorbance was measured at $700 \mathrm{~nm}$. Increasing absorbance of the reaction mixture indicates increasing reducing power. Results were expressed as a mean \pm standard deviation (SD) of 5 replicate measurements, with ascorbic acid and butylated hydroxytoluene (BHT) as a reference reducing agent. 


\subsubsection{Catalase activity}

Catalase activity (CAT) was measured by hydroperoxide reduction method [21]. $0.5 \mathrm{ml}$ of extract was mixed with $6.5 \mathrm{ml}$ of distilled water and $1 \mathrm{ml}$ of $1 \%$ $\mathrm{H}_{2} \mathrm{O}_{2}$. After thermostating for $30 \mathrm{~min}$ at $298 \mathrm{~K}$, the reaction was stopped by the addition of $5 \mathrm{ml}$ of $10 \%$ $\mathrm{H}_{2} \mathrm{SO}_{4}$. The content of the $\mathrm{H}_{2} \mathrm{O}_{2}$ reduced by the catalase was determined by the $1 \mathrm{~N} \mathrm{KMnO}_{4}$ solution by titration. Enzymatic activity can be calculated by the formula:

$$
\text { Activity }=\frac{1.7 \mathrm{~V}}{30 \cdot 0.5}
$$

where $V$ is a volume of $1 \mathrm{~N} \mathrm{KMNO}_{4}, \mathrm{ml} ; 30$ is incubation time, min and 0.5 is extract volume, $\mathrm{ml}$. This activity was compared with a commercialized medicament ENZIM containing a purified catalase $(5 \times 103 \mathrm{UC})$.

\subsection{Quantum Chemical Study}

Quantum chemical calculations have been performed by the HyperChem-7 package [22]. At the preliminary stage of calculations, the geometries of parent molecules in the gas phase have been first optimized using the semi-empirical PM3 method implemented in the HyperChem-7 program package. A search for optimal molecular geometries was performed using a combination of quenched dynamics and simulated annealing techniques at a constant temperature $(600 \mathrm{~K})$ as recommended. Next, the energy of the obtained conformers was minimized using the $\mathrm{MM}+$ force field and PM3 parametrization within the restricted Hartree- Fock (RHF) formalism. Geometry optimization was carried out using a Polak-Ribiere algorithm based on the conjugate gradient method with convergence set to $4.186 \mathrm{~J} / \mathrm{mol}$. The optimized structures with the minimum energy values were selected for further calculations. Prediction about the most possible antioxidant mechanism in gas phase was made.

Quantum chemistry is a powerful approach to theoretical prediction of the scavenging capacity of the compounds to ward radicals [23-27]. The radical scavenging mechanism is influenced by many molecular parameters (that can be calculated at different theoretical levels), such as the energy of the highest occupied molecular orbital $\left(E_{\text {НОмо }}\right.$ ), and the HOMO - LUMO gap $(\Delta E)$, absolute hardness $(\eta)$ and electronegativity $(\chi)$, electrophilicity index $(\omega)$, vertical ionization potentials $\left(I P_{v}\right)$, electron affinity $\left(E A_{v}\right)$. Vertical ionization potential $\left(I P_{v}\right)$ was determined according to Koopmans' theorem: $\left(I P_{v}=-E_{\text {НОМO }}\right)$. Electron affinity was determined according to formula: $E A_{v}=-E_{L U M O}$. Additionally, absolute hardness $(\eta)$ and electronegativity $(\chi)$ for the compounds under study were evaluated from HOMO and LUMO energies using the following formulae:

$$
\begin{aligned}
& \eta=\left(I P_{v}-E A_{v}\right) / 2 \\
& \chi=\left(I P_{v}+E A_{v}\right) / 2
\end{aligned}
$$

The molecular electrophilicity index $(\omega)$ was calculated from the relationship between $\eta$ and $\chi$ as:

$$
\omega=\frac{\chi^{2}}{2 \eta}
$$

\section{Results and Discussion}

\subsection{Chemical Profile of Extracts}

GC-MS data of individual compounds content in ethanol extraction, silicone and mixture solvents silicone and ethanol $(1: 5 \mathrm{v} / \mathrm{v})$ extraction are shown in Fig. 1 and Table 1. Each of the individual components present has its own function, so the plant extract can be used as a whole complex with a multifunctional action, and also to extract the necessary biologically active substances from it to provide the necessary properties. The extract obtained with the help of a mixture of solvents showed the presence of all the constituent components of the double extracts, the percentage of fatty acids, terpene alcohols, ethers, phenolic compounds was seen to increase, which indicates a more expedient process. Similarly as in the case of phenolic compounds, the highest levels of aldehydes (3-hexanone, benzaldehyde) were found in EtOH extract apricot pomace. From the GC-MS data obtained, it can be concluded that the EtOH extract contains a larger weight ratio of phenolic compounds, aldehydes, ethers, terpene alcohols, polysaccharides, and flavonoids; in turn, the silicone extract has a high fatty acid as well as terpene alcohols content. Significant differences were also observed in the contents of individual groups of phenolic compounds.

\subsection{Antioxidant Activity}

The antioxidant activity of the extracts was analyzed by several methods, because evaluation of antioxidant properties of plants cannot be carried out accurately by single universal method. In this study, the antioxidant activity of the ethanol and silicone extract was evaluated using 3 different assays.

\subsubsection{Evaluation of total antioxidant capacity}

The total antioxidant activity was measured by phosphomolybdate method [13]. Also, it is a quantitative one, since the antioxidant activity is expressed as the number of equivalents of ascorbic acid (mg/g plant extract). Extract of pomace apricot exhibited concentration dependent antioxidant capacity with respect to ascorbic acid equivalents (Table 2). Based on Table 2, it can be stated that the ethanol extract has more pronounced antioxidant properties $(460.86 \pm 2.63)$ than the extract obtained by cyclopentasiloxane $(199.56 \pm 6.12)$. The extract obtained with the help of cyclopentasiloxane and ethanol mixture is not inferior regarding its antioxidant properties than the extract obtained only with ethanol. 
Component composition of individual substances of apricot pomace extracts

\begin{tabular}{|c|c|c|c|c|}
\hline \multirow[b]{2}{*}{$\begin{array}{l}\text { Retention } \\
\text { time, min }\end{array}$} & \multirow[b]{2}{*}{ Name of the compound } & \multicolumn{3}{|c|}{ Quantitative ratio, $\%$} \\
\hline & & $\mathrm{EtOH}$ & D5 & $\begin{array}{l}\text { EtOH- } \\
\text { D5 }\end{array}$ \\
\hline 4.04 & Hexanol & - & 2.67 & 0.34 \\
\hline 5.34 & (Z)-3-Hexenol & 0.8 & 0.76 & - \\
\hline 6.81 & 3,4,5-Trihydroxybenzoic acid (Gallic acid) & 4.19 & - & - \\
\hline 7.23 & 2-Hexanone & 1.05 & 1.03 & 0.94 \\
\hline 7.69 & Manose & 0.24 & - & - \\
\hline 8.01 & 3-Hexanone & 1.72 & 0.54 & 0.53 \\
\hline 9.58 & Hexanal & 1.28 & 1.32 & 0.79 \\
\hline 10.06 & Benzaldehyde & 3.18 & 0.94 & 1.92 \\
\hline 11.96 & Heptanal & 0.64 & 2.18 & 1.02 \\
\hline 12.71 & Phenylacetaldehyde & 1.73 & 3.29 & 3.06 \\
\hline 14.01 & (E)-2-Hexenyl acetate & 1.06 & 2.78 & 0.53 \\
\hline 14.12 & $\begin{array}{c}(1 S, 3 R, 4 R, 5 R)-3-\{[(2 E)-3-(3,4-D i h y d r o x y p h e n y l) p r o p-2-e n o y l] o x y\}-1,4,5- \\
\text { trihydroxycyclohexanecarboxylicacid (Chlorogenicacid) }\end{array}$ & 3.82 & - & - \\
\hline 14.37 & 5-Butyloxolan-2-one $(\gamma$-octalactone $)$ & 0.71 & 2.03 & 1.98 \\
\hline 14.43 & endo-1,7,7-Trimethyl- bicyclo[2.2.1]heptan-2-ol (isoborneol) & 0.43 & 1.03 & 1.59 \\
\hline 14.92 & 2,6,6-Trimethylcyclohexene-1-carbaldehyde ( $\beta$-cyclocitral) & 3.24 & 5.17 & 4.27 \\
\hline 15.03 & Fructosa & 0.27 & - & - \\
\hline 15.42 & (2E,4E)-Deca-2,4-dienal & - & 3.65 & 2.81 \\
\hline 15.74 & 3-(3,4-Dihydroxyphenyl)-2-propenoic acid (Caffeic acid) & 2.71 & - & - \\
\hline 15.86 & (Z)-3,7-Dimethyl-2,6-octadien-1-ol (nerol) & 3.09 & 3.02 & 4.74 \\
\hline 16.74 & $(9 Z, 12 Z, 15 Z)-9,12,15$-Octadecatrienoic acid ( $\alpha$-Linolenicacid $)$ & 1.94 & 0.63 & 4.94 \\
\hline 16.98 & (2R,3S,4R,5R)-2,3,4,5,6-Pentahydroxyhexanal (D-Glucose) & 0.98 & - & - \\
\hline 17.06 & (2E)-3,7-Dimethyl-2,6-octadien-1-ol (geraniol) & 3.49 & 8.54 & 4.52 \\
\hline 17.29 & (9Z,12Z)-Octadeca-9,12-dienoic acid (linoleic acid) & 3.29 & 4.38 & 5.34 \\
\hline 18.24 & Hexadecanoicacid (palmitic acid) & 2.61 & 5.49 & 5.98 \\
\hline 18.32 & 3,7-Dimethylocta-1,6-dien-3-ol (linalool) & 3.32 & 3.06 & 2.71 \\
\hline 18.94 & 1-Tetradecanoic acid & 3.29 & - & 4.35 \\
\hline 19.60 & Octadecanoic acid (stearic acid) & 5.71 & 7.1 & 7.74 \\
\hline 19.62 & $(9 Z)$-Octadec-9-enoic acid & 4.01 & 6.29 & 6.98 \\
\hline 20.67 & (7aR)-5,6,7,7a-Tetrahydro-4,4,7a-trimethyl-2(4H)-benzofuranone & 2.04 & 2.05 & 2.18 \\
\hline 20.91 & 5-Pentyl-5-pentanolide $(\delta$-decalactone $)$ & - & 2.87 & 1.91 \\
\hline 21.09 & (Z)-3-Hexenyl butanoate & 2.91 & 1.77 & 1.24 \\
\hline 21.23 & (9Z)-Hexadec-9-enoic acid & - & - & 0.56 \\
\hline 22.18 & $\begin{array}{l}(1 \mathrm{R}, 2 \mathrm{~S}, 6 \mathrm{~S}, 7 \mathrm{~S}, 8 \mathrm{~S})-8 \text {-Isopropyl-1,3-dimethyltricyclo[4.4.0.0]dec-3-ene } \\
\text { ( } \alpha \text {-copaene) }\end{array}$ & 3.09 & 4.02 & 4.53 \\
\hline 23.07 & 2-(3,4-Dihydroxyphenyl)-3,5,7-trihydroxy-4H-chromen-4-one (Quercetin) & 7.1 & - & - \\
\hline 23.08 & 3-Cyclohexen-1-ol, 4-methyl-1-(1-methylethyl) (4-terpineol) & 6.24 & 4.98 & 5.54 \\
\hline 23.54 & 2-(4-Methylcyclohex-3-en-1-yl)propan-2-ol ( $\alpha$-terpineol) & 6.61 & 5.98 & 5.82 \\
\hline 23.82 & (3E)-4-(2,6,6-Trimethylcyclohex-1-en-1-yl)but-3-en-2-one $(\beta$-ionone $)$ & 0.47 & 1.97 & 2.24 \\
\hline 24.16 & (2R,3S)-2-(3,4-Dihydroxyphenyl)-3,4-dihydro-2H-chromene-3,5,7-triol (Catechin) & 2.94 & - & - \\
\hline 24.48 & (2E)-3-(4-Hydroxyphenyl)prop-2-enoic acid (p-Coumaric acid) & 1.94 & - & - \\
\hline 26.32 & Dihydro-5-octyl-2(3H)-furanone & 0.65 & 0.54 & 3.91 \\
\hline 26.79 & 3,7,11-Trimethyl-1,6,10-dodecatrien-3-ol (nerolidol) & 2.52 & 8.54 & 4.3 \\
\hline 27.21 & (2E,6E)-3,7,11-Trimethyldodeca-2,6,10-trien-1-ol (farnesol) & - & 1.38 & 0.69 \\
\hline 28.44 & 3,3',4',5,7-Pentahydroxyflavone (isoquercetin) & 1.74 & - & - \\
\hline 29.51 & Stigmasterol & 0.43 & - & - \\
\hline 30.08 & Eicosanic acid & 0.39 & - & - \\
\hline 30.92 & $\beta$-Sitosterol & 2.13 & - & - \\
\hline
\end{tabular}

Total antioxidant capacity of extracts obtained with different solvents

\begin{tabular}{|c|c|c|c|}
\hline Fruit extract & \multicolumn{3}{|c|}{ Total antioxidant capacity (mg ASE/g extract) } \\
\hline \multirow{2}{*}{ ACE } & EtOH & D5 & EtOH-D5 \\
\cline { 2 - 4 } & $460.86 \pm 2.63$ & $199.56 \pm 6.12$ & $447.62 \pm 7.4$ \\
\hline
\end{tabular}




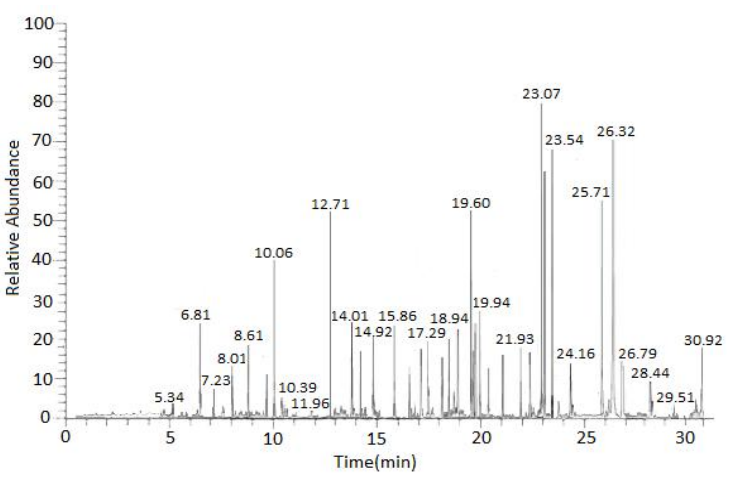

a)

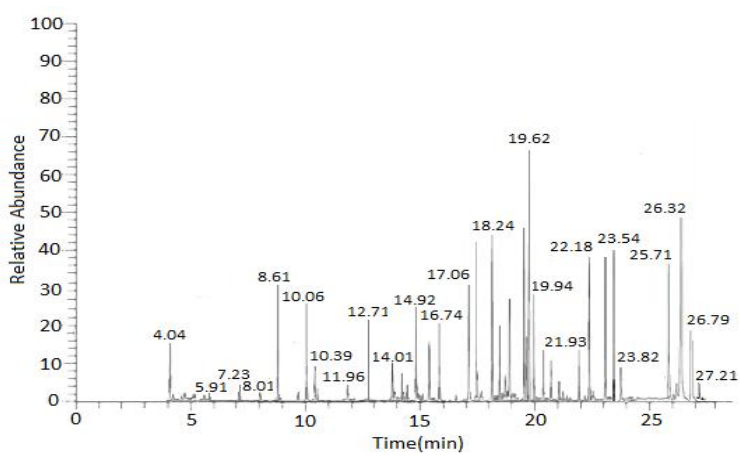

b)

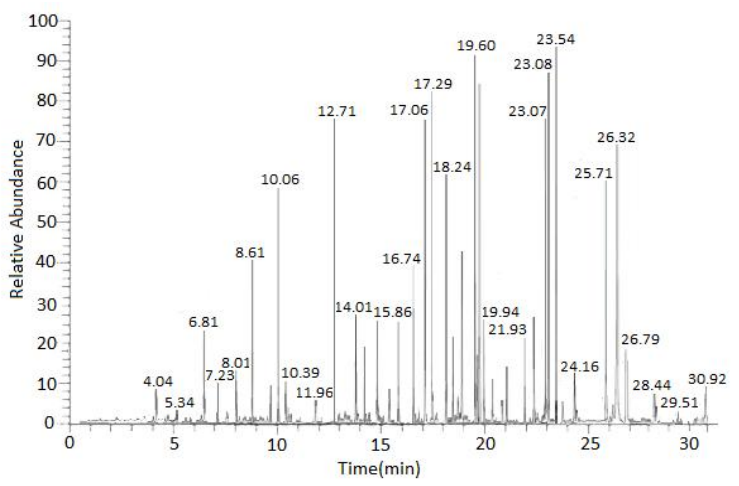

c)

Fig. 1. GC-MS spectral chromatogram of ACE: EtOH (a), D5 (b) and EtOH/D5 (1:5 v/v) (c)

This potent antioxidant activity may be attributed to its high phenolic and flavonoid contents. The total antioxidant activity of apricot pomace extracts is the result of individual activities of each of the antioxidant compounds present, such as tocopherols, carotenoids, and phenolic compounds, the latter being the major phytochemicals responsible for antioxidant activity of plant materials [28]. Moreover, these compounds render their effects via different mechanisms such as radical scavenging, metal chelation, inhibition of lipid peroxidation, quenching of singlet oxygen, and so on to act as antioxidants. Even if a sample exhibits high activity with one of these methods it does not always show similar good results with all other methods. Therefore, it is essential to evaluate samples accurately by several methods.

\subsubsection{Reducing power}

Reducing power is associated with antioxidant activity and can serve as a significant reflection of antioxidant activity. Compounds with a reducing power show that they are electron donors that have the ability to reduce oxidized intermediates of the processes of lipid peroxidation, they can act as primary and secondary antioxidants. Higher absorbance of the reaction mixture indicates higher reductive potential. Fig. 2 shows the concentration-absorbance curves for the reducing powers of the extracts. The reducing power of the extracts increased with increase in their concentrations. The extracts exhibited fairly good reducing power.

The highest reducing power, in comparison with the known powerful antioxidants such as ascorbic acid and BHT, has an ethanol extract. Its reducing power does not depend on concentration. A slightly less reducing power observed in the extract from the mixture of solvents of EtOH-D5 obtained with the ratio of $1: 5 \mathrm{v} / \mathrm{v}$, at the concentration of $1 \mathrm{mg} / \mathrm{ml}$ and above shows a stable result of reducing ability. For a silicone extract, the reducing power is lower than that of the above extracts, significantly depends on the concentration, and increases with increasing concentration. Because of the good reductive ability of researched extracts, it was evident that these extracts did show reductive potential and could serve as strong electron donors, terminating the radical chain reaction.

\subsubsection{Catalase activity}

Catalase, an enzyme belonging to the class of oxidoreductases, catalyzes the heterolytic cleavage of $\mathrm{O}-\mathrm{O}$ bonds in $\mathrm{H}_{2} \mathrm{O}_{2}$. Catalase reduces the formation of hydroxyl radical $\left(\mathrm{OH}^{\circ}\right)$, which is the most toxic of oxygen radicals. Catalase is always present in systems where electrons are transported with the participation of cytochromes, i.e. where the hydrogen peroxide is toxic to the cell. It is 
localized mainly in peroxisomes of cells, where its concentration reaches $10^{-6} \mathrm{~mol}$, and in the cytoplasm. The highest result of catalase activity was found in ethanol extract (1.93), although almost on an equal basis with
EtOH-D5 extract (1.74). Silicone extract has a lower catalase activity but has an average of 1.15 . It can be stated that the extracts under study can act as an inhibitor of the formation of free hydroxyl radicals.

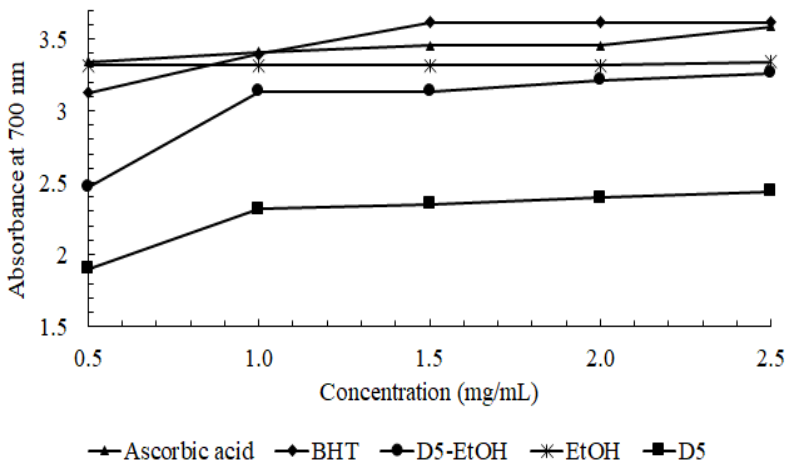

Fig. 2. Reducing power of extracts obtained with different solvents

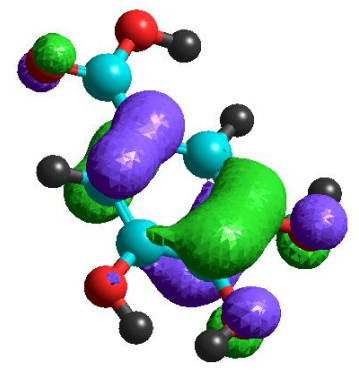

3,4,5-trihydroxybenzoic acid (1)
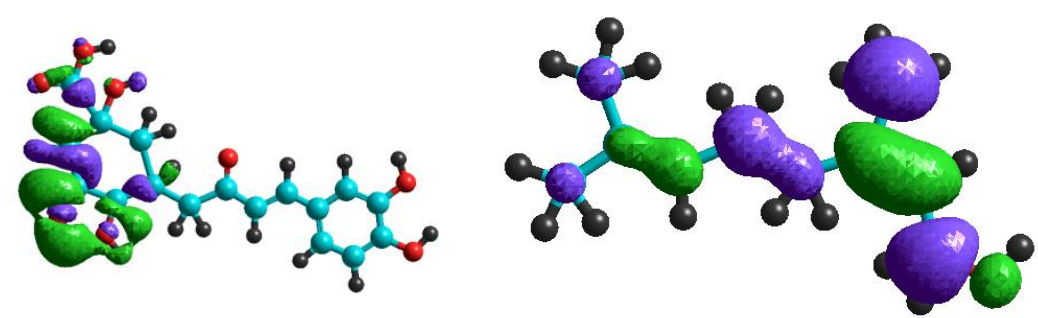

Chlorogenic acid (4)

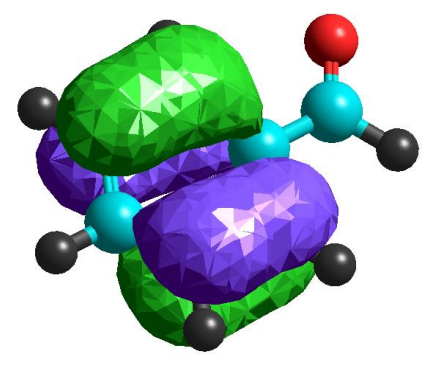

Benzaldehyde (2)
(Z)-3,7-dimethyl-2,6-octadien-1-ol (5)

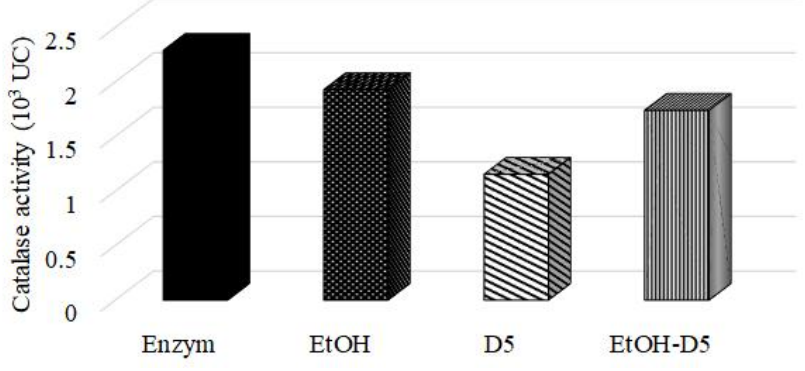

Fig. 3. Catalase activity of the extracts of apricot pomace

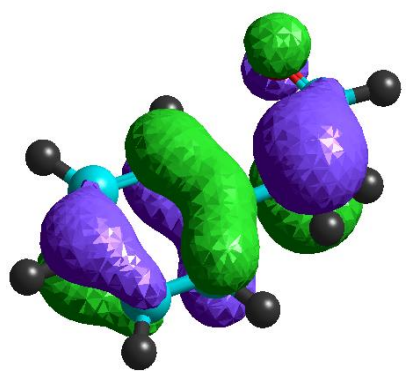

Phenylacetaldehyde (3)

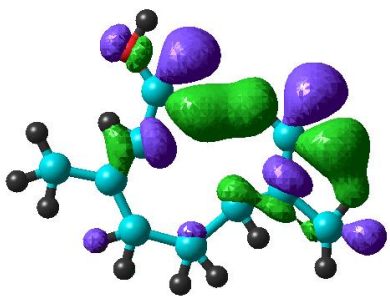

(2E)-3,7-Dimethyl-2,6-octadien-1-ol (6)

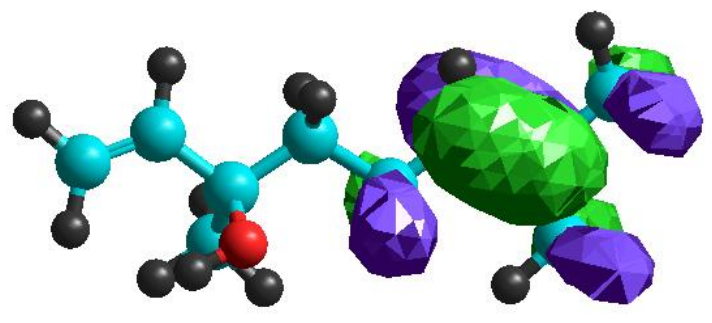

3,7-dimethylocta-1,6-dien-3-ol (linalool) (7)

Fig. 4. The HOMO orbital distribution of the tested molecules in the gas phase 


\subsection{Theoretical Studies. General Quantum-Chemical Characteristics of the Main compounds of the Apricot Pomace Extract}

Noticeably, the plant extract is a mixture of various components, which results in the complex antioxidative mechanism [25]. It is rather difficult to determine what components present in plant extract create their relatively high free radical scavenging potency. A theoretical calculation was conducted to investigate the antioxidant activity of the main compounds of apricot pomace extract. The molecules structure of the apricot pomace extract (1-8) obtained after a geometric optimization procedure is presented in Fig. 4. The results of quantum-chemical calculations of the energy parameters of molecules are presented in Tables 3 and 4.

Some descriptors relevant to free radical scavenging have also been computed: the energy of the highest occupied molecular orbital $\left(E_{\text {НОМО }}\right)$, the energy of the lowest unoccupied molecular orbital $\left(E_{L U M O}\right)$, and the HOMO-LUMO gap. Energies of the highest occupied molecular orbital $\left(E_{\text {НОмО }}\right)$ and the lowest unoccupied molecular orbital $\left(E_{L U M O}\right)$ as well as the value of the energy difference between the HOMO and LUMO (H-L gap, $(\Delta E)$ play a very important role in stability and reactivity of molecules.

Recent studies have pointed out the correlation between energy of HOMO and the free radical scavenging activity [26]. Molecules with lower HOMO energy are less likely to donate electrons. The electronic density distribution of HOMO enables the prediction of the most probable sites responsible for electron transfer and free radical attack (Fig. 4). A high density of HOMO is associated with more active redox sites in the tested molecules.

HOMO contains electrons, thus the $E_{\text {НОMO }}$ exhibits electron-donating ability of the molecule. The $E_{\text {НОмо }}$ values for compounds $1-8$, listed in Table 3 , increase in the following order: benzaldehyde, $(2 E)$-3,7-dimethyl-2,6octadien-1-ol (geraniol), 3,7-dimethylocta-1,6-dien-3-ol (linalool), phenylacetaldehyde, chlorogenic acid, (Z)-3,7dimethyl-2,6-octadien-1-ol (nerol), (2E)-3,7-dimethyl-2,6octadien-1-ol (geraniol).

On the other hand, the $E_{L U M O}$ characterizes the electron-accepting ability of the compound. The $E_{L U M O}$ values for compounds listed in Table 3 decrease in the following order: (Z)-3,7-dimethyl-2,6-octadien-1-ol (nerol), 3,7-dimethylocta-1,6-dien-3-ol (linalool), benzaldehyde, phenylacetaldehyde, 3,4,5-trihydroxybenzoic acid, (2E)-3,7-dimethyl-2,6-octadien-1-ol (geraniol), chlorogenic acid.

Table 3

Calculated quantum chemical properties for the most stable conformations of the major components of the apricot pomace extracts

\begin{tabular}{|c|c|c|c|}
\hline Compounds & $E_{\text {НОМО }}$ & $E_{L U M O}$ & HOMO-LUMO gap $(\Delta E)$ \\
\hline 3,4,5-Trihydroxybenzoic acid & -9.8385 & -1.0171 & 8.8213 \\
\hline Benzaldehyde & -10.2236 & -0.5566 & 9.6669 \\
\hline Phenylacetaldehyde & -8.1959 & -0.5983 & 7.5975 \\
\hline Chlorogenic acid & -7.2201 & -1.5062 & 5.7139 \\
\hline (Z)-3,7-Dimethyl-2,6-octadien-1-ol (nerol) & -5.7047 & -0.2765 & 5.4282 \\
\hline 2E-3,7-Dimethyl-2,6-octadien-1-ol (geraniol) & -5.1220 & -1.0406 & 4.0814 \\
\hline 3,7-Dimethylocta-1,6-dien-3-ol (linalool) & -8.2278 & -0.2836 & 7.9447 \\
\hline
\end{tabular}

Table 4

Calculated quantum chemical properties for the most stable conformations of the major components of the apricot pomace extracts

\begin{tabular}{|l|c|c|c|c|c|}
\hline \multicolumn{1}{|c|}{ Compounds } & $\begin{array}{c}\text { Ionization } \\
\text { potential } \\
I P_{v}\end{array}$ & $\begin{array}{c}\text { Electron } \\
\text { affinity } \\
E A_{v}\end{array}$ & $\begin{array}{c}\text { Electronegativity } \\
\chi\end{array}$ & $\begin{array}{c}\text { Hardness } \\
\eta\end{array}$ & $\begin{array}{c}\text { Electrophilicity } \\
\text { index } \\
\omega\end{array}$ \\
\hline 3,4,5-Trihydroxybenzoic acid & 9.8385 & 1.0171 & 5.4278 & 4.4106 & 0.2267 \\
\hline Benzaldehyde & 10.2236 & 0.5566 & 5.3901 & 4.8334 & 0.2068 \\
\hline Phenylacetaldehyde & 8.1959 & 0.5983 & 4.3971 & 3.7987 & 0.2632 \\
\hline Chlorogenic acid & 7.2201 & 1.5062 & 4.3632 & 2.8569 & 0.3500 \\
\hline (Z)-3,7-Dimethyl-2,6-octadien-1-ol (nerol) & 5.7047 & 0.2765 & 2.9906 & 2.7141 & 0.3684 \\
\hline (2E)-3,7-Dimethyl-2,6-octadien-1-ol (geraniol) & 5.1220 & 1.0406 & 3.0813 & 2.0407 & 0.4900 \\
\hline 3,7-Dimethylocta-1,6-dien-3-ol (linalool) & 8.2277 & 0.2837 & 4.2557 & 3.9722 & 0.2517 \\
\hline
\end{tabular}


A small energy gap between the HOMO and LUMO increases the antiradical activity. The $\Delta E$ gives information about the wavelengths the investigated compound can absorb, as well as its reactivity. The larger $\Delta E$ always refers to the lower chemical reactivity and higher kinetic stability of investigated species. For this reason, $\Delta E$ of investigated anthraquinones was estimated. The energy gap values for compounds listed in Table 3 increase in the following order: benzaldehyde, 3,4,5-trihydroxybenzoic acid, 3,7dimethylocta-1,6-dien-3-ol (linalool), phenylacetaldehyde, chlorogenic acid, (Z)-3,7-dimethyl-2,6-octadien-1-ol (nerol), (2E)-3,7-dimethyl-2,6-octadien-1-ol (geraniol). Quantum chemical descriptors, such as hardness, electronegativity, electrophilicity index may yield important information about the bioactivity of natural compounds. The molecule characterized by a low hardness is classified as a reactive one [24] and vice versa. It is obvious from Table 4 that compound (2E)-3,7-dimethyl-2,6-octadien-1-ol (geraniol) has the lowest hardness.

\section{Conclusions}

Ethanol (EtOH), silicone (D5) and a mixture of silicone and ethanol extracts of apricot pomace provides a rich source of antioxidants and chemical compounds. This study showed that extraction solvents play an important role in the extraction of important bioactive groups and as a result of the manifestation of antioxidant properties. The results of this study show that the samples of apricot pomace extracts studied prepared with the help of solvents such as ethanol, silicone, mixtures of silicone and ethanol, in the ratio of $1: 5(\mathrm{v} / \mathrm{v})$ have antioxidant properties at a high level, reaching all known antioxidants like ascorbic acid and BHT. Antioxidant activity grows in order of ethanol extract $>$ extract obtained by a mixture of solvents $>$ silicone (D5). The ethanolic fraction of apricot pomace demonstrated the strongest antioxidant activity, which could be attributed to its highest content of phenolics and flavonoids. The above studies, during which the antioxidant activity of the extracts of the apricot pomace was established, make it possible to recommend this plant as a mean for correcting the functional state of the free radical oxidation system.

\section{References}

[1] Okino Delgado C., Fleuri L.: Food Rev. Int., 2015, 32, 1. https://doi.org/10.1080/87559129.2015.1041183

[2] Gullón B., Gullón P., Eibes G. et al.: Sci. Total Environ., 2018, 645. 533. https://doi.org/10.1016/j.scitotenv.2018.07.155

[3] Lemes A., Álvares G., Egea M. et al.: Bioresour. Technol., 2016, 222, 210. https://doi.org/10.1016/j.biortech.2016.10.001

[4] Shakeel A., Mudasir A., Babu L. et al.: J. Adv. Res., 2016, $7,17$. https://doi.org/10.1016/j.jare.2015.02.007

[5] Skiba M., Vorobyova V., Pivovarov O. et al.: East.-Eur. J. Enterpr. Technol., 2018, 2, 51.

[6] Kumar K., Yadav A., Kumar V. et al.: Bioresour. Bioprocess., 2017, 4, 18. https://doi.org/10.1186/s40643-017-0148-6

[7] Maluf D., Gonçalves M., D’Angelo R. et al.: Cosmetics, 2018, 5, 46. https://doi.org/10.3390/cosmetics5030046
[8] Chyhyrynets O., Fateev Y., Vorobiova V. et al.: Mater. Sci., 2016, 51, 644. https://doi.org/10.1007/s11003

[9] Vorob'iova V., Chyhyrynets' O., Vasyl'kevych O.: Mater. Sci., 2015, 50, 726. https://doi.org/10.1007/s11003-015-9778-z

[10] Vorobyova V., Chygyrynets' O., Skiba M.: Int. J. Corros. Scale Inhibit., 2018, 7, 185. https://doi.org/10.17675/2305-6894-2018-7-2-6 [11] Vorobyova V., Chygyrynets' O., Skiba M.: J. Chem. Technology and Metallurgy, 2018, 53, 336.

[12] Naheed A., Seema S., Alam K. et al.: Colloid Surf. B, 2010, 81, 81. https://doi.org/10.1016/j.colsurfb.2010.06.029

[13] Prabakaran M., Hemapriya V., Kim S. et al.: Arab. J. Sci. Eng., 2018, 1. https://doi.org/10.1007/s13369-018-3398-5

[14] Liao L., Moa S., Luo H. et al.: J. Colloid Interf. Sci., 2018, 520, 41. https://doi.org/10.1016/j.jcis.2018.02.071

[15] Abbas M., Kaddour S., Trari M.: J. Ind. Eng. Chem., 2014, 20,

745. https://doi.org/10.1016/j.jiec.2013.06.03

[16] Cheaib D., El Darra N., Rajha H.: Sci. World J., 2018, 2018.

https://doi.org/10.1155/2018/8249184

[17] Das A., Dewanjee S.: Comput. Phytochem., 2018, 75.

https://doi.org/10.1016/B978-0-12-812364-5.00003-1

[18] Johnsen L., Skou P., Khakimov B., Bro R.: J. Chromatogr. A,

2017, 1503, 57. https://doi.org/10.1016/j.chroma.2017.04.052

[19] Pilar P., Pineda M.: Anal. Biochem., 1999, 269, 337.

https://doi.org/10.1006/abio.1999.4019

[20] Canabady-Rochellea L., Harscoat-Schiavoa C., Kessler V. et al.: Food Chem., 2015, 183, 129.

https://doi.org/10.1016/j.foodchem.2015.02.147

[21] Maheshwari D., Yogendra K., Saroj K. et al.: Food Chem. Toxicol., 2011, 49, 2422. https://doi.org/10.1016/j.fct.2011.06.061 [22] HyperChemTM, Hypercube, Inc., Ontario, Canada 1994.

[23] Wang A., Lu Y., Du X. et al.: Struct. Chem., 2018, 29, 1067. https://doi.org/10.1007/s11224-018-1090-8

[24] Parr R., von Szentpály L., Liu S.: Am. Chem. Soc., 1999, 121, 1922. https://doi.org/10.1021/ja983494x

[25] Ardjani A., Mekelleche S.: J. Mol. Model., 2016, 22, 302.

https://doi.org/10.1007/s00894-016-3160-4

[26] Stobiecka A.: Flavour Fragr. J., 2015, 30, 399.

https://doi.org/10.1002/ffj.3256

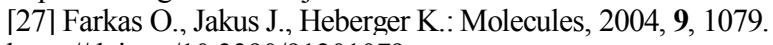
https://doi.org/10.3390/91201079

[28] Michiels J., Kevers C., Pincemail J.et al.: Food Chem., 2012, 130, 986. https://doi.org/10.1016/j.foodchem.2011.07.117

Received: November 09, 2018 / Revised: November 20, 2018 / Accepted: April 10, 2019

\section{АНТИОКСИДАНТНА АКТИВНІСТЬ ТА ФІТОХІМІЧНИЙ СКРІНІНГ ЕКСТРАКТУ ЖМИХУ АБРИКОСУ: ЕКСПЕРИМЕНТАЛЬНІ ТА ТЕОРЕТИЧНІ ДОСЛІДЖЕННЯ}

Анотація. Вивчено компонентний склад та антиоксидантні властивості екстракту жмиха абрикосу (ЕЖА). 3 використанням етанолу (ЕtOH), силікону (D5) і сумімі силікону та етанолу проведено екстрагування жмиху абрикосу. За допомогою методу газової хромато-мас-спектроскопї (ГХ-МС) визначено компонентний склад. Проведено оичнювання антиоксидантної здатності ЕЖА (знижувальна здатність заліза(III), загальна антиоксидантна здатність $і$ каталазна активність). Розраховано квантово-хімічні індекси антиоксидантної активності, такі як енергія вищої зайнятої та нижчої вакантної молекулярних ор-

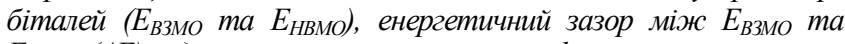
$E_{\text {Нвмо }}(\Delta E)$, індекс жорсткості та електрофільності та інші.

Ключові слова: компонентний склад, екстракт жсмиха абрикоса, квантово-хімічні показники, антиоксидантна активність. 